\title{
Correlations Between Yield and Morphological Characters in Puerto Rican and Columnaris Varieties of Coffea Arabica L. ${ }^{1}$
}

\section{T. Singh Dhaliwal ${ }^{2}$}

\section{INTRODUCTION}

The method of individual tree selection followed by progeny tests is commonly used for developing high-yielding strains of Arabica-type coffees. Yield data for several crops are usually necessary for selecting the individual high-yielding trees. The collection of such data involves considerable time and expense. When individual trees are to be selected from private plantations it is generally difficult to get cooperation to collect yield data. For these reasons, knowledge of the nature and extent of correlations between yield and morphological characters of trees can be a very useful aid in selecting high-yielding individual trees $(1,2,3) .^{3}$

The correlations between cherry yield and morphological characters of trees in 16 samples of commercially grown Arabica-type coffee varieties, Puerto Rican, and Columnaris, planted at three locations, were evaluated. The results from this study are briefly presented in this paper.

\section{MATERIALS AND METHODS}

The 16 samples of Puerto Rican and Columnaris varieties studied were grown at Castañer, Maricao, and Mayagüez under about 50-percent natural shade. They were accorded cultural practices generally as recommended in commercial coffee production (4). The trees were not trained or pruned in any way. Any tree which seemed to be bent from the start, broken, or otherwise damaged, was not included in the study. Cherry-yield data were collected for 2 to 17 crops. Additional information about the samples is given in table 1.

In 1958 , data from each tree were collected as to the following eight morphological characters:

1. Circumference of main stem measured at ground level.

2. Number of stems.

1 This investigation was carried on under the Federal Grant Research Project Hatch 74, Coffe Breeding in Puerto Rico.

2 Plant Breeder, Agricultural Experiment Station, Mayagüez Campus, University of Puerto Rico, Río Piedras, P.R. The author is very grateful to Mr. A. Cruz Miret and Mrs. Ada M. de Ray, of this Station, for their cooperation in analyzing the data.

${ }^{3}$ Italic numbers in parentheses refer to Literature Cited, p. 37. 
Number of stems or upright growing shoots, an inch or more thick, and arising within 5 feet from ground level, were counted.

3. Height of tree measured from ground level to the apical bud.

4. Width of eanopy.

Maximum width or extent to which the canopy spread was measured.

5. Length of primary laterals.

The lengths of 3 primary lateral branches, taken at random at about the middle of the height of the tree, were measured and their average calculated.

6. Number of secondary laterals.

TABLE 1.-General information concerning the 16 samples of Puerto Rican and Columnaris varieties of coffee

\begin{tabular}{|c|c|c|c|c|c|c|c|}
\hline Sample & Variety & Location & $\begin{array}{c}\text { Approx- } \\
\text { imate } \\
\text { altitude }\end{array}$ & Soil type & $\begin{array}{l}\text { Planting } \\
\text { distance }\end{array}$ & $\mid \begin{array}{c}\text { Approx- } \\
\text { imate } \\
\text { year } \\
\text { planted }\end{array}$ & $\begin{array}{c}\text { Crops and } \\
\text { years of } \\
\text { harvest }\end{array}$ \\
\hline & & & Feet & & Feet & & Number \\
\hline 1 & Puerto Rican & Mayagüez & 80 & Coloso clay & $8 \times 8$ & 1931 & $17(1934-50)$ \\
\hline 2 & Columnaris & do. & 80 & do. & $8 \times 8$ & 1931 & $17(1934-50)$ \\
\hline 3 & Puerto Rican & Castañer & 2,000 & Alonso clay & $8 \times 8$ & 1943 & $2(1956-57)$ \\
\hline 4 & do. & do. & 2,200 & do. & $8 \times 8$ & 1943 & $2(1956-57)$ \\
\hline 5 & do. & do. & 1,800 & do. & $8 \times 8$ & 1943 & $2(1956-57)$ \\
\hline 6 & do. & do. & 2,000 & do. & $8 \times 8$ & 1943 & $2(1956-57)$ \\
\hline 7 & do. & do. & 1,800 & do. & $8 \times 8$ & 1943 & $2(1956-57)$ \\
\hline 8 & do. & do. & 2,400 & do. & $8 \times 8$ & 1943 & $2(1956-57)$ \\
\hline 9 & do. & do. & 1,600 & do. & $8 \times 8$ & 1945 & $9(1950-58)$ \\
\hline 10 & do. & do. & 1,600 & do. & $12 \times 12$ & 1945 & $9(1950-58)$ \\
\hline 11 & do. & Maricao & 1,100 & Catalina clay & $8 \times 8$ & 1945 & $9(1950-58)$ \\
\hline 12 & do. & do. & 1,100 & do. & $12 \times 12$ & 1945 & $9(1950-58)$ \\
\hline 13 & Columnaris & Castañer & 1,600 & Alonso clay & $8 \times 8$ & 1945 & $9(1950-58)$ \\
\hline 14 & do. & do. & 1,600 & do. & $12 \times 12$ & 1945 & $9(1950-58)$ \\
\hline 15 & do. & Maricao & 1,100 & Catalina clay & $8 \times 8$ & 1945 & $9(1950-58)$ \\
\hline 16 & do. & do. & 1,100 & do. & $12 \times 12$ & 1945 & $9(1950-58)$ \\
\hline
\end{tabular}

Average number of secondary lateral branches was found for the primary lateral branches studied for character 5 .

7. Number of nodes.

Average number of nodes was found for the primary lateral branches studied for character 5 .

8. Length of internodes.

Average length of internodes was found on the primary lateral branches studied for character 5 .

The data were analyzed to find out whether cherry yield varies significantly with variation in the above-mentioned tree characters.

In the statistical analysis of the data the tree characters were considered as the independent variables and the cherry yield as the dependent variable. 


\section{RESULTS}

\section{PUERTO RICAN VARIETY}

For each sample the correlation coefficients $(r)$ for cherry yield $(Y)$ and each tree character $(X)$ were calculated. The statistical significances of the correlations between yield and each tree character were determined by the $\mathrm{F}$ test. The results are presented in table 2 . The correlation between yield and tree character 1, circumference of main stem, was found to be positive and significant in all the samples. The correlations between yield and tree characters: 4 , Width of canopy; 5 , length of primary laterals; and 7 , number of nodes, were found to be positive and significant in more than half the number of samples.

Multiple-correlation analysis was made to measure the significance of the combined effect of tree characters: 1, Circumference of main stem; 4 , width of canopy; 5 , length of primary laterals; 7 , number of nodes and 2 , number of stems on yield. The combined effect was significant in all the four samples studied. These tree characters explained from 39.53 to 54.56 percent of the variation in yield (table 3 ).

Multiple-correlation analysis was made also to measure the significance of the combined effect of tree characters: 1, Circumference of main stem; 4 , width of canopy; 5 , length of primary laterals; 7 , number of nodes; and 3 , height on yield. The effect was significant in all the four samples studied. These characters explained from 35.86 to 58.63 percent of the variation in yield (table 3 ).

The above results indicate that coffee trees with relatively thick main stems at ground level produce relatively high yields. It is also apparent that coffee trees of the Puerto Rican variety with a relatively wide canopy, long primary laterals, more nodes on primary laterals, more stems and more height in general, give relatively high yields. Consequently these characters are helpful in selecting high-yielding individual coffee trees from plantings which are old enough to be in full production and also within which the environmental conditions are uniform.

\section{COLUMNARIS VARIETY}

For each sample the correlation coefficients $(r)$ for cherry yield $(Y)$ and tree characters $(X)$ were calculated. The statistical significances of the correlations between yield and each tree character were determined by the $\mathrm{F}$ test. The results are presented in table 4 . The correlation between yield and tree character: 1, Circumference of main stem, was found to be positive and significant in all the samples. The correlations between yield and tree characters: 3 , Height; 4 , width of canopy; and 6 , number of second- 
TABLE 2.-Correlation coefficients (r) for cherry yield $(\mathbf{Y})$ and tree characters

(X) in 11 samples of the Puerto Rican variety of coffee ${ }^{1}$

\begin{tabular}{|c|c|c|c|c|c|c|c|c|c|}
\hline \multirow[b]{2}{*}{ Sample } & \multirow[b]{2}{*}{$N^{2}$} & \multicolumn{8}{|c|}{ Data for tree characters indicated } \\
\hline & & $\begin{array}{l}1 \text {, circum- } \\
\text { ference of } \\
\text { main stem }\end{array}$ & $\begin{array}{l}2 \text {, number } \\
\text { of stems }\end{array}$ & height & $\begin{array}{l}\text { 4, width } \\
\text { of canopy }\end{array}$ & $\begin{array}{l}5 \text {, length } \\
\text { of primary } \\
\text { laterals }\end{array}$ & $\begin{array}{l}6, \text { number } \\
\text { of secondary } \\
\text { laterals }\end{array}$ & $\begin{array}{l}7, \text { number } \\
\text { of nodes }\end{array}$ & $\begin{array}{l}\text { 8, length } \\
\text { of internodes }\end{array}$ \\
\hline 1 & 50 & $0.329 x^{3}$ & $-0.154 N S^{5}$ & $0.037 N S$ & $-0.036 N S$ & $-0.156 N S$ & $-0.186 N S$ & $0.173 N S$ & $-0.306 x$ \\
\hline 3 & 100 & $.263 x x^{4}$ & $.015 N S$ & $.326 x x$ & $.307 x x$ & $.519 x x$ & $.196 x$ & $.490 x x$ & $-.171 N S$ \\
\hline 4 & 99 & $.488 x x$ & $.489 x x$ & $.090 N S$ & $.548 x x$ & $.141 N S$ & $-.018 N S$ & $.191 N S$ & $-.214 x$ \\
\hline 5 & 100 & $.279 x x$ & $.325 x x$ & $.376 x x$ & $.441 x x$ & $.058 N S$ & $-.032 N S$ & $.084 N S$ & $-.071 N S$ \\
\hline 6 & 100 & $.295 x x$ & $.163 N S$ & $.415 x x$ & $.397 x x$ & $.256 x x$ & $.219 x$ & $.293 x x$ & $-.076 N S$ \\
\hline 7 & 48 & $.300 x$ & $.222 N S$ & $.156 N S$ & $.300 x$ & $.398 x x$ & $.232 N S$ & $.346 x$ & $-.091 N S$ \\
\hline 8 & 46 & $.461 x x$ & $.237 N S$ & $.155 N S$ & $.206 N S$ & $.422 x x$ & $.289 N S$ & $.501 x x$ & $-.058 N S$ \\
\hline 9 & 76 & $.619 x x$ & $.148 N S$ & $.332 x x$ & $.651 x x$ & $.324 x x$ & $.215 x$ & $.235 x$ & $.029 N S$ \\
\hline 10 & 87 & $.403 x x$ & $.374 x x$ & $.156 N S$ & $.670 x x$ & $.243 x$ & $-.096 \mathrm{NS}$ & $.205 x$ & $.051 N S$ \\
\hline 11 & 78 & $.547 x x$ & $.378 x x$ & $.409 x x$ & $.501 x x$ & $.164 N S$ & $-.018 N S$ & $.109 N S$ & $.088 N S$ \\
\hline 12 & 69 & $.321 x x$ & $.543 x x$ & $.187 N S$ & $.569 x x$ & $.330 x x$ & $.058 N S$ & $.270 x$ & $-0.005 N S$ \\
\hline Times & $x x$ & 9 & 5 & 5 & 8 & 6 & - & 3 & - \\
\hline Do. & $x$ & 2 & - & - & 1 & 1 & 3 & 4 & 2 \\
\hline Do. & $N S$ & 一 & 6 & 6 & 2 & 4 & 8 & 4 & 9 \\
\hline
\end{tabular}

1 The tree characters are described in the text and information about the samples is given in table 1 .

${ }^{2} \mathrm{~N}=$ Number of trees in sample.

${ }^{3} x=$ F value significant at the 5-percent probability level.

${ }^{4} x x=\mathrm{F}$ value significant at the 1-percent probability level.

${ }^{5} N S=\mathrm{F}$ value not significant. 
ary laterals; were also found to be positive and significant in more than half the number of samples.

Multiple correlation analysis was made to measure the significance of

TABLE 3.-Multiple correlation analysis to measure the significance and extent of the combined effect of several tree characters on cherry yield in 4 samples of Puerto Rican variety ${ }^{1}$

\begin{tabular}{|c|c|c|c|c|}
\hline Sample & $N^{2}$ & Tree characters & $F$ value & $\begin{array}{l}\text { Variation in yield } \\
(Y) \text { explained by } \\
\text { the tree charac- } \\
\text { ters }(X)\end{array}$ \\
\hline & & ter & & Percent \\
\hline 9 & 76 & $\begin{array}{l}1 \text { (circumference of main stem), } 4 \text { (width of } \\
\text { canopy), } 5 \text { (length of primary laterals), } 7 \\
\text { (number of nodes), } 2 \text { (number of stems) }\end{array}$ & $16.81 x x^{3}$ & 54.56 \\
\hline 9 & 76 & $\begin{array}{l}1 \text { (circumference of main stem), } 4 \text { (width of } \\
\text { canopy), } 5 \text { (length of primary laterals) } 7 \\
\text { (number of nodes), } 3 \text { (height) }\end{array}$ & $19.84 x x$ & 58.63 \\
\hline 10 & 87 & $\begin{array}{c}1 \text { (circumference of main stem), } 4 \text { (width of } \\
\text { canopy), } 5 \text { (length of primary laterals), } 7 \\
\text { (number of nodes), } 2 \text { (number of stems) }\end{array}$ & $17.47 x x$ & 51.89 \\
\hline 10 & 87 & $\begin{array}{l}1 \text { (circumference of main stem), } 4 \text { (width of } \\
\text { canopy), } 5 \text { (length of primary laterals), } 7 \\
\text { (number of nodes), } 3 \text { (height) }\end{array}$ & $15.66 x x$ & 49.16 \\
\hline 11 & 78 & $\begin{array}{c}1 \text { (circumference of main stem), } 4 \text { (width of } \\
\text { canopy), } 5 \text { (length of primary laterals), } 7 \\
\text { (number of nodes), } 2 \text { (number of stems) }\end{array}$ & $9.41 x x$ & 39.53 \\
\hline 11 & 78 & $\begin{array}{l}1 \text { (circumference of main stem), } 4 \text { (width of } \\
\text { canopy), } 5 \text { (length of primary laterals), } 7 \\
\text { (number of nodes), } 3 \text { (height) }\end{array}$ & $10.38 x x$ & 41.90 \\
\hline 12 & 69 & $\begin{array}{l}1 \text { (circumference of main stem), } 4 \text { (width of } \\
\text { canopy), } 5 \text { (length of primary laterals), } 7 \\
\text { (number of nodes), } 2 \text { (number of stems) }\end{array}$ & $9.82 x x$ & 43.79 \\
\hline 12 & 69 & $\begin{array}{l}1 \text { (circumference of main stem), } 4 \text { (width of } \\
\text { canopy), } 5 \text { (length of primary laterals), } 7 \\
\text { (number of nodes), } 3 \text { (height) }\end{array}$ & $7.05 x x$ & 35.86 \\
\hline
\end{tabular}

${ }_{1}^{1}$ The tree characters are described in the text and information about the samples is given in table 1.

${ }^{2} N=$ Number of trees in sample.

${ }^{3} x x=\mathrm{F}$ value significant at the 1-percent probability level.

the combined effect of tree characters: 1 , Circumference of main stem; 3 , height; 4 , width of canopy; 6 , number of secondary laterals; and 5, length of primary laterals - on yield. The effect was significant in all the four samples studied. These tree characters explained from 34.48 to 60.23 percent of the variation in yield (table 5).

Multiple correlation analysis was made also to measure the significance 
TABLE 4-Correlation coefficients ( $\mathbf{r})$ for cherry yield $(\mathbf{Y})$ and tree characters (X) in 5 samples of Columnaris variety of coffee ${ }^{1}$

\begin{tabular}{|c|c|c|c|c|c|c|c|c|c|}
\hline \multirow{2}{*}{ Sample } & \multirow{2}{*}{$N^{2}$} & \multicolumn{8}{|c|}{ Data for tree characters indicated } \\
\hline & & $\begin{array}{l}\text { 1, circumfer- } \\
\text { ence of main } \\
\text { stem }\end{array}$ & $\begin{array}{l}2, \underset{\text { number of }}{\text { stems }} \\
\text {. }\end{array}$ & 3 , height & $\begin{array}{l}\text { 4, width of } \\
\text { canopy }\end{array}$ & $\begin{array}{c}5 \text {, length of } \\
\text { primary laterals }\end{array}$ & $\begin{array}{l}\text { 6, number of } \\
\text { secondary } \\
\text { laterals }\end{array}$ & $7, \underset{\text { number of }}{\text { nodes }}$ & $\begin{array}{l}\text { 8, length of } \\
\text { internodes }\end{array}$ \\
\hline 2 & 46 & $0.643 x x^{4}$ & $-0.343 x^{3}$ & $0.220 N S^{5}$ & $-0.137 N S$ & $-0.246 N S$ & $0.080 \mathrm{NS}$ & $-0.123 N S$ & $-0.127 N S$ \\
\hline 13 & 81 & $.528 x x$ & $.021 N S$ & $.351 x x$ & $.247 x$ & $.193 N S$ & $.252 x$ & $.002 N S$ & $-.041 N S$ \\
\hline 14 & 93 & $.664 x x$ & $.109 N S$ & $.279 x x$ & $.441 x x$ & $.310 x x$ & $.206 x$ & $.264 x$ & $-.017 N S$ \\
\hline 15 & 72 & $.620 x x$ & $.220 N S$ & $.317 x x$ & $.505 x x$ & $.424 x x$ & $.235 x$ & $.415 x x$ & $-.094 N S$ \\
\hline 16 & 72 & $.715 x x$ & $.039 N S$ & $.420 x x$ & $.618 x x$ & $.100 N S$ & $-.113 N S$ & $.070 N S$ & $.040 N S$ \\
\hline Times & $x x$ & 5 & - & 4 & 3 & 2 & 一 & 1 & 一 \\
\hline & $x$ & - & 1 & $=-$ & 1 & 一 & 3 & 1 & 一 \\
\hline & NS & - & 4 & 1 & 1 & 3 & 2 & 3 & 5 \\
\hline
\end{tabular}

1 The tree characters are described in the text and information about the samples is given in table 1.

${ }^{2} N=$ Number of trees in sample.

${ }^{3} x=\mathrm{F}$ value significant at the 5-percent probability level.

${ }^{4} x x=\mathrm{F}$ value significant at the 1-percent probability level.

${ }^{5} N S=\mathrm{F}$ value not significant. 
of the combined effect of tree characters: 1, Circumference of main stem; 3 , height; 4 , width of canopy; 6 , number of secondary laterals; and 7 , number of nodes - on yield. The effect was significant in all the four samples

TABLE 5.-Multiple correlation analysis to measure the significance and extent of combined effect of tree characters on cherry yield in 4 samples of

Columnaris variety ${ }^{1}$

\begin{tabular}{|c|c|c|c|c|}
\hline Sample & $N^{2}$ & Tree characters & $F$ value & $\begin{array}{l}\text { Variation (per- } \\
\text { cent) in yield }(Y) \\
\text { explained by the } \\
\text { tree characters } \\
(X)\end{array}$ \\
\hline 13 & 81 & $\begin{array}{l}1 \text { (circumference of main stem), } 3 \text { (height), } \\
4 \text { (width of canopy), } 6 \text { (number of second- } \\
\text { ary laterals), } 5 \text { (length of primary lat- } \\
\text { erals) }\end{array}$ & $7.90 x x^{3}$ & 34.48 \\
\hline 13 & 81 & $\begin{array}{l}1 \text { (circumference of main stem), } 3 \text { (height), } \\
4 \text { (width of canopy), } 6 \text { (number of second- } \\
\text { ary laterals), } 7 \text { (number of nodes) }\end{array}$ & $7.88 x x$ & 34.43 \\
\hline 14 & 93 & $\begin{array}{l}1 \text { (circumference of main stem), } 3 \text { (height), } \\
4 \text { (width of canopy), } 6 \text { (number of second- } \\
\text { ary laterals), } 5 \text { (length of primary laterals) }\end{array}$ & $20.00 x x$ & 53.48 \\
\hline 14 & 93 & $\begin{array}{l}1 \text { (circumference of main stem), } 3 \text { (height), } \\
4 \text { (width of canopy), } 6 \text { (number of second- } \\
\text { ary laterals), } 7 \text { (number of nodes) }\end{array}$ & $20.10 x x$ & 53.60 \\
\hline 15 & 72 & $\begin{array}{l}1 \text { (circumference of main stem), } 3 \text { (height), } \\
4 \text { (width of canopy), } 6 \text { (number of second- } \\
\text { ary laterals), } 5 \text { (length of primary lat- } \\
\text { erals) }\end{array}$ & $13.43 x x$ & 50.43 \\
\hline 15 & 72 & $\begin{array}{l}1 \text { (circumference of main stem), } 3 \text { (height), } \\
4 \text { (width of canopy), } 6 \text { (number of second- } \\
\text { ary laterals), } 7 \text { (number of nodes) }\end{array}$ & $14.06 x x$ & 51.58 \\
\hline 16 & 72 & $\begin{array}{l}1 \text { (circumference of main stem), } 3 \text { (height), } \\
4 \text { (width of canopy), } 6 \text { (number of second- } \\
\text { ary laterals), } 5 \text { (length of primary lat- } \\
\text { erals) }\end{array}$ & $19.99 x x$ & 60.23 \\
\hline 16 & 72 & $\begin{array}{l}1 \text { (circumference of main stem), } 3 \text { (height), } \\
4 \text { (width of canopy), } 6 \text { (number of second- } \\
\text { ary laterals), } 7 \text { (number of nodes) }\end{array}$ & $19.81 x x$ & 60.01 \\
\hline
\end{tabular}

1 The tree characters are described in the text, and information about the samples is given in table 1 .

${ }^{2} N=$ Number of trees in sample.

${ }^{3} x x=\mathrm{F}$ value significant at the 1 -percent probability level.

studied. These tree characters explained from 34.43 to 60.01 percent of the variation in yield (table 5).

The above results show that coffee trees of the Columnaris variety, with a relatively thick main stem at ground level, give relatively high yields. 
The results also indicate that coffee trees with relatively greater height, wide canopy, more secondary laterals, long primary laterals, and more nodes on primary laterals, in general produce relatively high yields. Thus these characters are useful in selecting high-yielding individual coffee trees from plantings which are old enough to be in full production and also within which the environmental conditions are uniform.

For both varieties, the main tree characters for selection of high-yielding trees are circumference of stem at ground level and width of canopy.

\section{SUMMARY}

The correlations between cherry yield and morphological characters of trees were calculated for 16 samples of Puerto Rican and Columnaris varieties of Coffea arabica L.

In the Puerto Rican variety, yield was positively and significantly correlated with circumference of main stem at ground level in all the 11 samples. Yield was also positively and significantly correlated with width of canopy, length of primary lateral branches, and number of nodes per primary lateral branch, in more than half the samples.

In the Columnaris variety, cherry yield had a positive and significant correlation with the circumference of the main stem at ground level in all the five samples. Yield also had positive and significant correlation with height of tree, width of canopy, and number of secondary lateral branches per primary lateral branch, in more than half the samples.

Circumference of stem at ground level and width of canopy were the main tree characters correlated with yield in both varieties.

\section{RESUMEN}

Las correlaciones entre los rendimientos de fruta y los caracteres morfológicos de los arbustos de café se calcularon en 16 muestras de las variendades Puerto Rico y Columnaris, ambas pertenecientes al Coffea arabica $\mathrm{L}$.

En 11 muestras de la variedad Puerto Rico, el rendimiento de fruta estuvo correlacionado en forma positiva y significativa con la circunferencia del tallo principal, medida a nivel del terreno. También, en más de la mitad de las muestras, el rendimiento estuvo correlacionado en forma positiva y significativa con la anchura del dosel del arbusto, el largo de sus ramas laterales primarias y el número de nudos en cada rama lateral primaria.

En todas las cinco muestras de la variedad Columnaris, el rendimiento de fruta estuvo correlacionado en forma positiva y significativa con la circunferencia del tallo principal, medida a nivel del terreno. También, en más de la mitad de las muestras el rendimiento estuvo correlacionado en 
forma positiva y significativa con la altura del arbusto, la anchura del dosel y el número de ramas laterales secundarias en cada rama lateral primaria.

La circunferencia del tallo del arbusto, medida a nivel del terreno, y la anchura del dosel fueron los caracteres principales del arbusto, en ambas variedades, que estuvieron correlacionados con el rendimiento de fruta.

\section{LITERATURE CITED}

1. Singh Dhaliwal, T., Desarrollo de estirpes o biotipos superiores de café mediante la selección, la hibridación y la propagación asexual, para su cultivo en Puerto Rico, Rev. de Agr. de P.R. 44(2): 59-87, 1957.

2. - Progress Report of the Project Coffee Breeding in Puerto Rico, 1954-65, Agr. Expt. Sta., Univ. P.R., Misc. Publ. 53, 1965.

3. - Morales Muñoz, A., Jordán Molero, J., and Meléndez González, P., Development of Arabica Type Coffee Selections for Commercial Production in Puerto Rico, Agr. Exp. Sta., Univ. P.R. Misc. Pub. (Manuscript submitted for publication in 1966.)

4. Wellman, Frederick L., Recommendaciones para Mejorar el Cultivo del Café en Puerto Rico, Est. Exp. Agr. de la Univ. de P.R., Bol. 153, 1960. 